\title{
Price and quality of livestock feeds in suburban markets of West Africa's Sahel: Case study from Bamako, Mali
}

\author{
A.A. Ayantunde ${ }^{1,2 *}$ M. Blummel ${ }^{3}$ \\ E. Grings ${ }^{4}$ A.J. Duncan ${ }^{5}$
}

\section{Keywords}

Livestock - Suburban agriculture Feed - Price - Quality - Nutritive value - Commodity market - Sahel.

\begin{abstract}
Summary
In West African Sahel cities, livestock husbandry such as smallholder dairy production and livestock (cattle, sheep and goat) fattening has become popular among livestock owners to meet food needs for the household, and for income generation. The increasing importance of urban and suburban agriculture, particularly livestock husbandry in the region, has led to a rapid increase in livestock populations in most of the cities. As a result of this increase and the associated growth in the demand for feeds, feed markets have sprung up in many cities and towns of West Africa's Sahel. A survey of livestock feed markets was conducted in five markets in Bamako, Mali. Prices of livestock feeds were monitored monthly from January to December 2010. In addition, feed samples were collected from the markets for laboratory analysis to determine their nutritional quality. Results showed that the prices of cowpea hay and groundnut haulm were consistently higher than those of other feeds throughout the year. The price of cowpea hay ranged from 367 FCFA/kg dry matter (DM) (1 USD $\approx 500$ FCFA) in October, i.e. immediately after harvest, to $667 \mathrm{FCFA} / \mathrm{kg}$ DM in August, i.e. in the wet season. Results also showed that there was no relationship between price and quality for all feed types. However, prices and quality of feeds differed significantly across seasons suggesting that the season was a major determinant for the price of livestock feeds in suburban areas of West Africa's Sahel.
\end{abstract}

\section{INTRODUCTION}

There has been a rapid growth in the urban population in West Africa as in most sub-Saharan African countries in the last four decades (27). According to an African Development Bank report (1), in 2010 the share of the African urban population was about $36 \%$ and was projected to increase to $50 \%$ and $60 \%$, by 2030 and 2050 , respectively. This rapid urbanization is associated with spatial concentration of people of different cultural and geographical origins, different educational and professional backgrounds, and diversified livelihood strategies. Thus, a large proportion of urban people have been involved in agricultural activities such as crop farming, livestock husbandry and vegetable production since the 1980s (21). The main drivers for this trend include declining

1. International Livestock Research Institute (ILRI), BP 320, Bamako, Mali.

2. Present address: ILRI, CIFOR, 06 BP 9478, Ouagadougou, Burkina Faso.

3. ILRI, c/o ICRISAT, Andhra Pradesh, India.

4. Department of Animal Science, South Dakota State University, Brookings, SD, USA; formerly at ILRI, IITA, Ibadan, Nigeria.

5. ILRI, Addis Ababa, Ethiopia.

* Corresponding author

Tel.: +226503047 42; Fax: +22650302930

E-mail: a.ayantunde@cgiar.org prospects of securing 'white collar' jobs with government ministries and agencies due to the Structural Adjustment Programs of the 1980s and 1990s, a generally low level of education among rural migrants, and the growing demand for food by the urban population (27). In Sahelian cities of West Africa, livestock husbandry such as smallholder dairy production and animal (cattle, sheep and goat) fattening has become widespread to meet household food needs and for income generation (12). Sheep fattening in suburban areas of West Africa's Sahel is increasingly becoming an important economic activity and has been mainly driven by the Tabaski, the Islamic festival of Eid-al-Kabir $(5,9,16)$. It is particularly attractive to poor farmers including women because of its low initial investment, rapid turnover rate, social acceptance and easy market access. The main strategy is to fatten young, lean male sheep, born on the farm or, more often, purchased on the open market, over a two to three month period, each farmer fattening between one and five animals (5).

This has led to a rapid increase in the livestock population in most cities and large towns in the region (11). Mali's Government reports $(8,13)$ show that in Bamako the cattle population increased from 8,000 to 32,086 head from 1989 to 2012, whereas the sheep and goat populations during the same period increased from 5,000 to 80,686 head, i.e. an average annual growth rate of $6 \%$ and $13 \%$, 
for cattle and small ruminants, respectively, compared to a national average annual growth rate of $4.4 \%$ and $7.4 \%$ for the same species, respectively. Livestock husbandry in urban and suburban areas of West Africa's Sahel is increasing because of the growing demand for livestock products and because well-to-do government officials and entrepreneurs, who are taking advantage of the prevailing accessibility of the market, are investing in livestock enterprises.

Feed is the main challenge to livestock husbandry in urban and suburban areas of West Africa's Sahel because of its scarcity during the dry season and the limited access to grazing areas $(5,11$, 21). Most livestock keepers therefore depend on purchased feeds, often at high prices and influenced by seasonal variations. As a result of the increase in the livestock population and the associated growth in the demand for feeds, feed markets have sprung up in many cities and towns in the region. These livestock feed markets are usually located near livestock markets and they mainly sell crop residues, agricultural by-products such as cottonseed cake and cereal bran, concentrate feed from the small-scale feed industry, besides leaves from various shrubs and perennial sources. Information on the price and quality of feeds sold at these markets is important for optimization of livestock feeding strategies and enhancement of resource use efficiency in urban and suburban livestock production systems. The objective of the present study was to assess price variations for different feed types across seasons in suburban feed markets, and to determine whether there was a relationship between price and quality of livestock feeds.

\section{MATERIALS AND METHODS}

\section{Study site}

A survey was conducted in five livestock feed markets in Bamako in Mali, located in the areas of Lafiabougou, Sabalibougou, Faladje, Niamana and Boulkassoumbougou. These markets also sold livestock (cattle, sheep and goats). They were selected because of their relatively large size and year-round operations by feed sellers, and their three-kilometer minimum distance from one another. This ensured a sufficient number of sellers to select from for the survey which lasted for 12 months. All five markets were easily accessible by road. During the surveys, we did not collect data on the sales volume, turnover, origin of the feeds and characteristics of feed buyers but focused mainly on data collection of feed prices and quality.

\section{Feed market survey}

Prices of livestock feeds were monitored monthly in the five markets from January to December, 2010. For the monthly survey, five feed sellers in each market were randomly selected every month and interviewed by an enumerator in the local language. By interviewing five sellers per market we ensured that at least $20 \%$ of the total number of feed sellers in each market was sampled as there were about 20 feed sellers per market. Information on the price of every livestock feed was collected from the five feed sellers interviewed in each market. Information on the price of cereal grains (maize, millet, sorghum and rice) and legume grains (cowpea and groundnut) was also collected monthly from those among the five markets that sold food items. In addition, samples of all feeds present in the market were collected from one feed seller in each market for laboratory analysis to determine nutritional quality. In total, 294 feed samples were collected and processed for analysis. To establish the price of the feeds according to weight, particularly that of crop residues, we bought feeds from the sellers in each market every month, which were air dried then weighed. Apart from crop residues, the other feed types such as cereal bran, cottonseed cake and concentrate feeds were usually sold at a predefined weight, mostly in bags of $50 \mathrm{~kg}$ and $100 \mathrm{~kg}$.

\section{Cost-benefit analysis of sheep fattening}

To assess cost implications from livestock feed prices for sheep fattening in suburban areas of West Africa's Sahel, we formulated balanced rations based on two major feed types found in the markets, i.e. cowpea hay and concentrates for ruminants (Table I). The diet included either cowpea hay, as it is commonly used for sheep fattening in the region in combination with other feed ingredients (4), or a concentrate for sheep fattening because of its year-round availability and low price; it reduced the feeding cost, the price of cowpea hay being higher than that of the concentrates. Both cowpea-hay-based and concentrate-based diets contained $15 \%$ crude protein (on a dry matter [DM] basis) with fixed ingredients, i.e. bush hay (20\% of the diet on DM basis) and cereal bran (10\% of the diet on DM basis). The energy requirements of sheep were met in both diets according to AFRC recommendations (2). The cost implications of both formulated diets were assessed under four scenarios: (i) early dry season sales of sheep during an ordinary period, (ii) early dry season sales at the Tabaski, (iii) late dry season sales during an ordinary period, and (iv) late dry season sale at the Tabaski, when the sales price is always at least twice that of the ordinary period. The scenarios were tested in the early and late dry seasons when sheep fattening is usually carried out in the West African Sahel.

\section{Laboratory analyses}

Feed samples collected from the feed markets were analyzed for $\mathrm{DM}$, ash content, nitrogen, fiber components (NDF and ADF), metabolizable energy (ME) and in vitro organic matter digestibility (IVOMD) using the near infrared reflectance spectroscopy (NIRS) technique after grinding ( $2 \mathrm{~mm}$ sieve). NIRS is an indirect analytical method based on the development of empirical models in which the concentration of a feed constituent is predicted from complex spectral data (6) as presented in Table II. Crude protein was estimated from nitrogen content (nitrogen x 6.25). Details on the NIRS prediction of sample values are presented in Table III.

\section{Statistical analysis}

Data analysis was performed with SAS (26) using the general linear model (GLM) procedures for variance and regression analyses. For analysis of the variance model, response (dependent) variables were price and nutritional quality (DM, ash, crude protein, fiber components, ME and IVOMD), whereas season was the independent variable. A calendar year was divided into three seasons: wet (June to September), early dry (October to January), and late dry (February to May). In the analysis, the season was considered as a binary categorical variable with a value of either 0 or 1 . Unless otherwise specified, the level of significance was set at $p<0.05$.

\section{RESULTS}

\section{Price variations of different livestock feeds}

Results showed that each feed seller sold between four and ten types of livestock feeds. The major feed types sold were cowpea hay, groundnut haulm, cottonseed cake, bush hay (consisting mainly of Andropogon gayanus and Schizachyrium exile), cereal bran (this included maize bran, millet bran, sorghum bran and rice bran), browse (shrub/tree fodder), and concentrates for ruminants (for maintenance and fattening from a local feed industry). The factory labels of the nutrient composition of the concentrate feeds read as follows: the maintenance feed contained $13 \%$ crude 
Table I

Diet formulation for sheep fattening and costs based on cowpea hay or concentrates for ruminants ${ }^{1}$

\begin{tabular}{|c|c|c|c|c|}
\hline Feed & $\%$ in the diet & CP (\% DM) & ME (MJ/day $)^{2}$ & $\begin{array}{l}\text { Cost of } 100 \mathrm{~kg} \text { DM diet } \\
\left(\mathrm{FCFA}^{3}\right)\end{array}$ \\
\hline \multicolumn{5}{|c|}{ Early dry season - diet based on cowpea hay } \\
\hline Bush hay & 20 & 1.25 & 1.77 & 2,520 \\
\hline Cereal bran & 10 & 11.88 & 1.26 & 1,350 \\
\hline Cowpea hay & 52 & 15.75 & 7.06 & 22,204 \\
\hline Cottonseed cake & 18 & 29.63 & 2.06 & 2,934 \\
\hline Total & 100 & 15 & 12.15 & 29,008 \\
\hline \multicolumn{5}{|c|}{ Early dry season - diet based on concentrates for ruminants } \\
\hline Bush hay & 20 & 1.25 & 1.77 & 2,520 \\
\hline Cereal bran & 10 & 11.88 & 1.26 & 1,350 \\
\hline Concentrate & 63 & 18.19 & 8.66 & 10,395 \\
\hline Cottonseed cake & 7 & 29.63 & 0.82 & 1,141 \\
\hline Total & 100 & 15 & 12.51 & 15,406 \\
\hline \multicolumn{5}{|c|}{ Late dry season - diet based on cowpea hay } \\
\hline Bush hay & 20 & 1.63 & 1.83 & 3,420 \\
\hline Cereal bran & 10 & 12.81 & 1.26 & 1,450 \\
\hline Cowpea hay & 55 & 16.13 & 7.42 & 32,120 \\
\hline Cottonseed cake & 15 & 30.13 & 1.80 & 2,490 \\
\hline Total & 100 & 15 & 12.29 & 39,480 \\
\hline \multicolumn{5}{|c|}{ Late dry season - diet based on concentrates for ruminants } \\
\hline Bush hay & 20 & 1.63 & 1.83 & 3,420 \\
\hline Cereal bran & 10 & 12.81 & 1.26 & 1,450 \\
\hline Concentrate & 62 & 17.69 & 8.54 & 9,672 \\
\hline Cottonseed cake & 8 & 30.13 & 0.96 & 1,328 \\
\hline Total & 100 & 15 & 12.59 & 15,870 \\
\hline
\end{tabular}

CP: crude protein; DM: dry matter; ME: metabolizable energy

1 The diet for fattening ram contains 15\% CP (DM basis) with fixed feeds: bush hay (20\% of the diet on DM basis), cereal bran (10\% of the diet on DM basis). To reach $15 \% \mathrm{CP}(\mathrm{DM})$, the diet was balanced using cottonseed cake and cowpea hay or concentrates for ruminants. The daily feed offered for a $25-\mathrm{kg}$ ram for fattening was estimated at $1.5 \mathrm{~kg}$ DM including allowance for left-over. The duration of fattening was 90 days. The energy requirement (ME, MJ/day) for a $25-\mathrm{kg}$ ram for maintenance and growth (assumed average daily gain of $100 \mathrm{~g} /$ day) was estimated at $6 \mathrm{MJ} /$ day (AFRC, 1993).

${ }^{2}$ ME supply from feed ingredients (MJ/day) was calculated as: MJ/kg DM in the feed (from Table II) multiplied by the proportion of the ingredient in the diet, multiplied by the daily offer $(1.5 \mathrm{~kg} \mathrm{DM})$. For example, for bush hay in the early dry season, the ME supply/day was: $(5.9 \times 0.2) \times 1.5=1.77 \mathrm{MJ} / \mathrm{day}$

$31 \mathrm{USD} \approx 500 \mathrm{FCFA}$

protein, $4 \%$ ether extract, $12 \%$ crude fiber, $2 \%$ calcium, $0.5 \%$ phosphorus; and the fattening feed contained $15 \%$ contained crude protein, $5 \%$ ether extract, $6 \%$ crude fiber, $1.5 \%$ calcium, $0.85 \%$ phosphorus. We did not find any cereal straws (sorghum, millet or maize straws) throughout the year, perhaps because of the low demand and of their bulkiness which makes transport difficult.

The prices of cowpea hay and groundnut haulm were consistently higher than those of other feeds throughout the year (Table IV). The price of cowpea hay ranged from 367 FCFA $/ \mathrm{kg}$ DM (1 USD $\approx 500$ FCFA at time of study) in October immediately after harvest, to $667 \mathrm{FCFA} / \mathrm{kg} \mathrm{DM}$ in August, i.e. in the wet season (Table IV). Generally, the price of crop residues (cowpea hay and groundnut haulm) corresponded with availability; it was highest during the wet season (June to September) and lowest immediately after harvest (October and November). The prices of agricultural by-products, such as cottonseed cake and cereal bran, and of concentrate feeds did not vary significantly across the seasons, suggesting adequate year round availability. The price of legume residues (cowpea hay and groundnut haulm) was almost twice that of grain for most of the year except in the three months following harvest (October, November and December) (Figure 1). The prices of cowpea hay and groundnut haulm were on average 556 and $505 \mathrm{FCFA} / \mathrm{kg} \mathrm{DM}$, respectively, whereas the price of grain was 333 and 329 FCFA $/ \mathrm{kg}$ DM, respectively. The price of cereal bran ranged between 131 and $146 \mathrm{FCFA} / \mathrm{kg} \mathrm{DM}$ and was consistently lower than that of grain throughout the year (Figure 1).

\section{Variations in nutritional quality of livestock feeds}

In all seasons, cottonseed cake had a significantly $(\mathrm{p}<0.05)$ higher crude protein content but significantly lower metabolizable energy than other feed types except bush hay (Table II). Bush hay had the lowest crude protein content and the highest fiber content (NDF and ADF) in all seasons compared to other feed types (Table II). The nutritional contents of cowpea hay and groundnut haulm were similar to that of concentrate feeds in terms of ash content, ME and IVOMD in all seasons. The crude protein content and IVOMD of cereal bran were significantly lower than that of cowpea hay and groundnut haulm (Table II), suggesting a lower nutritional quality 


\section{Table II}

Nutritional quality (g/kg DM except for ME which is MJ/kg DM; mean \pm standard error) and price $\left(F C F A^{1} / \mathrm{kg} \mathrm{DM}\right.$ ) of different feed types sold at five feed markets in Bamako, Mali, based on the season

\begin{tabular}{|c|c|c|c|c|c|c|c|}
\hline Feed type & Ash & Crude Protein & NDF & ADF & ME & in vitro $\mathrm{OMD}$ & Price \\
\hline \multicolumn{8}{|c|}{ Wet season ${ }^{2}$ (June, July, August, September) } \\
\hline Cowpea hay & $96 \pm 6^{a}$ & $217 \pm 13^{b}$ & $485 \pm 25^{b}$ & $341 \pm 23^{b}$ & $9.5 \pm 0.1^{\mathrm{a}}$ & $685 \pm 11^{\mathrm{a}}$ & $658 \pm 9^{a}$ \\
\hline Groundnut haulm & $84 \pm 3^{a}$ & $157 \pm 7^{c}$ & $446 \pm 17^{b}$ & $307 \pm 16^{b}$ & $9.4 \pm 0.1^{\mathrm{a}}$ & $656 \pm 8^{a}$ & $617 \pm 6^{\mathrm{a}}$ \\
\hline Cottonseed cake & $61 \pm 3^{b}$ & $292 \pm 11^{a}$ & $467 \pm 13^{b}$ & $303 \pm 19^{b}$ & $7.6 \pm 0.2^{b}$ & $567 \pm 13^{b}$ & $169 \pm 5^{c}$ \\
\hline Bush hay & $41 \pm 9^{c}$ & $36 \pm 6^{d}$ & $834 \pm 37^{a}$ & $556 \pm 23^{\mathrm{a}}$ & $6.1 \pm 0.5^{c}$ & $399 \pm 32^{c}$ & $196 \pm 8^{b}$ \\
\hline Concentrate & $91 \pm 2^{\mathrm{a}}$ & $191 \pm 9^{b}$ & $389 \pm 12^{c}$ & $139 \pm 21^{d}$ & $9.4 \pm 0.1^{\mathrm{a}}$ & $665 \pm 9^{a}$ & $161 \pm 4^{\mathrm{c}}$ \\
\hline Cereal bran & $72 \pm 4^{b}$ & $152 \pm 9^{c}$ & $371 \pm 24^{\mathrm{c}}$ & $98 \pm 26^{d}$ & $9.3 \pm 0.4^{\mathrm{a}}$ & $647 \pm 28^{a}$ & $142 \pm 5^{\mathrm{c}}$ \\
\hline Browse & $74 \pm 6^{b}$ & $189 \pm 11^{b}$ & $457 \pm 31^{\mathrm{b}}$ & $238 \pm 11^{\mathrm{c}}$ & $9.5 \pm 0.3^{\mathrm{a}}$ & $646 \pm 9^{a}$ & $149 \pm 14^{\mathrm{C}}$ \\
\hline \multicolumn{8}{|c|}{ Early dry season ${ }^{2}$ (October, November, December, January) } \\
\hline Cowpea hay & $83 \pm 3^{a}$ & $157 \pm 10^{b}$ & $452 \pm 17^{c}$ & $299 \pm 13^{b}$ & $9.1 \pm 0.2^{\mathrm{a}}$ & $642 \pm 11^{\mathrm{a}}$ & $427 \pm 14^{\mathrm{a}}$ \\
\hline Groundnut haulm & $86 \pm 2^{\mathrm{a}}$ & $146 \pm 6^{b}$ & $437 \pm 18^{c}$ & $306 \pm 15^{b}$ & $9.2 \pm 0.1^{\mathrm{a}}$ & $638 \pm 9^{a}$ & $378 \pm 8^{\mathrm{a}}$ \\
\hline Cottonseed cake & $58 \pm 1^{b}$ & $296 \pm 7^{a}$ & $490 \pm 10^{c}$ & $322 \pm 11^{b}$ & $7.5 \pm 0.2^{b}$ & $565 \pm 12^{b}$ & $162 \pm 4^{b}$ \\
\hline Bush hay & $27 \pm 3^{c}$ & $13 \pm 1^{d}$ & $863 \pm 7^{a}$ & $552 \pm 15^{\mathrm{a}}$ & $5.9 \pm 0.3^{c}$ & $392 \pm 16^{c}$ & $126 \pm 5^{c}$ \\
\hline Concentrate & $88 \pm 2^{a}$ & $182 \pm 9^{b}$ & $397 \pm 10^{c}$ & $124 \pm 20^{c}$ & $9.2 \pm 0.1^{\mathrm{a}}$ & $651 \pm 10^{\mathrm{a}}$ & $165 \pm 5^{b}$ \\
\hline Cereal bran & $82 \pm 7^{a}$ & $129 \pm 7^{c}$ & $419 \pm 24^{c}$ & $136 \pm 34^{c}$ & $8.4 \pm 0.3^{\mathrm{a}}$ & $586 \pm 18^{b}$ & $134 \pm 3^{b c}$ \\
\hline Browse & $46 \pm 14^{b}$ & $155 \pm 11^{b}$ & $549 \pm 39^{b}$ & $289 \pm 14^{b}$ & $8.6 \pm 0.1^{a}$ & $585 \pm 9^{b}$ & $101 \pm 6^{c}$ \\
\hline \multicolumn{8}{|c|}{ Late dry season ${ }^{2}$ (February, March, April, May) } \\
\hline Cowpea hay & $89 \pm 4^{\mathrm{a}}$ & $161 \pm 13^{b}$ & $468 \pm 22^{c}$ & $320 \pm 18^{b}$ & $9.0 \pm 0.2^{b}$ & $635 \pm 17^{a}$ & $584 \pm 23^{a}$ \\
\hline Groundnut haulm & $88 \pm 4^{\mathrm{a}}$ & $139 \pm 7^{b}$ & $436 \pm 17^{c}$ & $315 \pm 15^{b}$ & $9.1 \pm 0.1^{b}$ & $633 \pm 9^{a}$ & $522 \pm 11^{\mathrm{a}}$ \\
\hline Cottonseed cake & $55 \pm 1^{b}$ & $301 \pm 6^{a}$ & $477 \pm 12^{c}$ & $318 \pm 12^{b}$ & $7.9 \pm 0.2^{c}$ & $593 \pm 11^{b}$ & $167 \pm 5^{c}$ \\
\hline Bush hay & $46 \pm 7^{c}$ & $20 \pm 3^{d}$ & $832 \pm 11^{\mathrm{a}}$ & $536 \pm 9^{a}$ & $6.1 \pm 0.1^{d}$ & $408 \pm 8^{\mathrm{C}}$ & $171 \pm 7^{c}$ \\
\hline Concentrate & $87 \pm 2^{\mathrm{a}}$ & $177 \pm 8^{b}$ & $408 \pm 12^{c}$ & $130 \pm 22 c$ & $9.2 \pm 0.1^{b}$ & $648 \pm 9^{a}$ & $158 \pm 3^{c}$ \\
\hline Cereal bran & $98 \pm 8^{a}$ & $128 \pm 10^{c}$ & $443 \pm 16^{c}$ & $187 \pm 21^{c}$ & $8.4 \pm 0.3^{c}$ & $592 \pm 19^{b}$ & $145 \pm 4^{\mathrm{c}}$ \\
\hline Browse & $44 \pm 1^{c}$ & $128 \pm 4^{\mathrm{c}}$ & $553 \pm 10^{b}$ & $306 \pm 16^{b}$ & $10.2 \pm 0.1^{\mathrm{a}}$ & $680 \pm 5^{a}$ & $237 \pm 18^{b}$ \\
\hline
\end{tabular}

DM: dry matter; NDF and ADF: fiber components; ME: metabolizable energy; OMD: organic matter digestibility

11 USD $\approx 500$ FCFA

${ }^{2}$ Comparison of each feed type across seasons showed significant differences $(\mathrm{p}<0.05)$ for the nutritional quality of the following feeds: browse (crude protein and ME were higher in wet season than in late dry season); cereal bran (ash content was higher in late dry season than in wet season); cowpea hay (crude protein and in vitro OMD were higher in wet season than in early and late dry seasons); bush hay (crude protein was higher in wet season than in early and late dry seasons).

Values with different superscript letters within the same column denote significant differences $(\mathrm{p}<0.05)$ between means for each season.

\section{Table III}

Validation of NIRS equations for the prediction of quality of feed resources

$\begin{array}{lcccc}\text { Variable } & \begin{array}{c}\text { Num. } \\ \text { samples }\end{array} & \begin{array}{c}\text { Prediction } \\ \text { error }\end{array} & \mathbf{R}^{2} & \text { GH } \\ \text { DM } & 147 & 0.358 & 0.814 & 1.120 \\ \text { Ash } & 147 & 1.842 & 0.726 & 1.120 \\ \text { Nitrogen } & 147 & 0.244 & 0.966 & 1.120 \\ \text { ME } & 147 & 0.242 & 0.952 & 1.120 \\ \text { IVOMD } & 147 & 2.239 & 0.923 & 1.120 \\ \text { NDF } & 804 & 2.721 & 0.965 & 0.973 \\ \text { ADF } & 804 & 1.959 & 0.947 & 0.973\end{array}$

NIRS: near infrared reflectance spectroscopy

GH: distance between the sample and the calibration database. Distances $>3$ are considered as outliers.

DM: dry matter, ME: Metabolizable energy; IVOMD: in vitro organic matter digestibility; NDF and ADF: fiber components

Mali's specific database was used for sample analysis for DM, ash, nitrogen, ME and IVOMD, whereas the global database was used for analysis of $\mathrm{NDF}$ and $\mathrm{ADF}$. of the former. Comparison of the nutritional quality of each feed type across the three seasons showed that the quality (ash, crude protein, NDF, ADF, ME and IVOMD) of concentrates, cottonseed cake and cereal bran did not vary significantly. The crude protein contents of cowpea hay and of bush hay were significantly higher in the wet season than in the early and late dry season. The crude protein content and ME of browse species were significantly higher in the wet season than in the late dry season.

\section{Relationship between price and feed quality}

The analysis of variance did not show a relationship between price and feed quality, in other words the quality of feed did not influence the price at the market for all feed types. This implies that feeds of the same quality were sold at different prices depending on the season and market. Results further showed that the price and nutritional quality of most of the feeds varied across seasons (Table V). The prices of cowpea hay, groundnut haulm, bush hay and browse were significantly affected by the season (Table V). Prices of these feeds declined as the season progressed from wet to dry except for browse species in which case the price increased significantly in the late dry season compared to the wet season. 

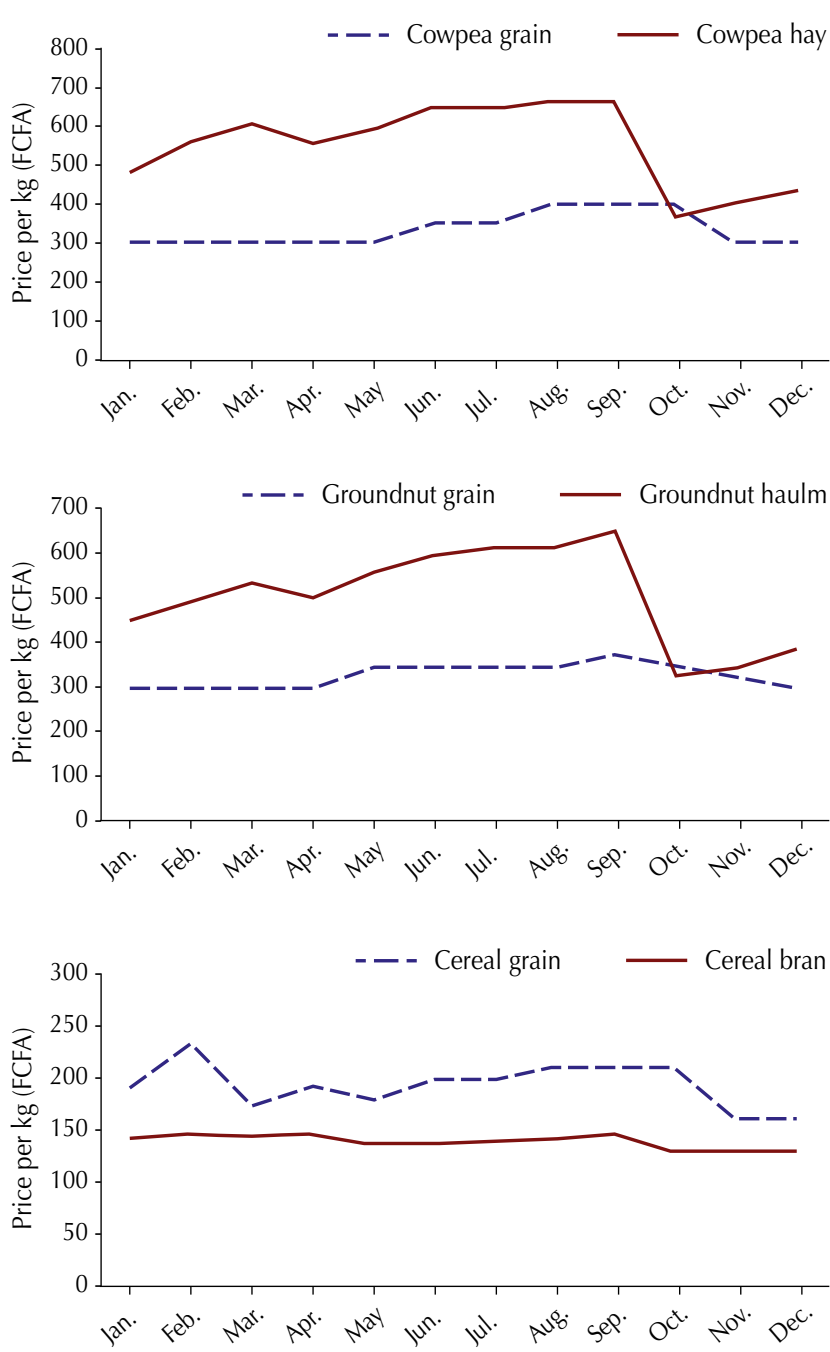

Figure 1: Comparison between grain prices and by-products or residues; 1 USD $\approx 500$ FCFA.
The season also had a significant effect on the crude protein content of browse species, cowpea hay and bush hay.

\section{Cost implications of livestock feed prices for sheep fattening in suburban areas}

The analysis of cost and benefit of sheep fattening showed that concentrates for ruminants can be used as substitutes for cowpea hay or groundnut haulm for sheep fattening in suburban areas in the region (Table I). The results also suggested that it was not economically profitable to fatten sheep with cowpea-hay-based diet in both the early and late dry seasons if the animals were destined to be sold during the ordinary period (Table VI). If the animals were sold during the Tabaski when the sales price was high, there could be positive net returns from fattening with a cowpea-hay-based diet in the early dry season. The cost-benefit analysis also suggested that it was more profitable to fatten sheep with a concentrate-based diet than with a cowpea-hay based diet in both the early dry and late dry seasons (Table VI).

\section{DISCUSSION}

The results obtained from the five monitored markets confirmed the common observation that livestock feeds are expensive in urban and suburban areas of West Africa's Sahel (5, 10, 11, 15, 19, 22 ). The prices of bush hay and cowpea hay in our study agreed with the ranges between 65 and $300 \mathrm{FCFA} / \mathrm{kg} \mathrm{DM}$, and between 330 and $800 \mathrm{FCFA} / \mathrm{kg} \mathrm{DM}$, respectively, reported for livestock productions in suburban Niamey in Niger by Bayala et al. (5) and Diogo et al. (11). In suburban areas of Niger, Bayala et al. (5) reported high prices between 125 and $351 \mathrm{FCFA} / \mathrm{kg}$ DM for hay of Zornia glochidiata. The feed prices observed in our study were much higher than $25 \mathrm{FCFA} / \mathrm{kg}$ DM for bush hay and 75 FCFA $/ \mathrm{kg}$ DM for groundnut haulm reported by Ayantunde et al. (3) in feed markets in rural areas in Southwestern Niger, and 148 FCFA $/ \mathrm{kg}$ DM for groundnut haulm reported by Bayala et al. (5) in rural

\section{Table IV}

Monthly price variations for different feed types (FCFA $1 / \mathrm{kg}^{\mathrm{D}} \mathrm{DM}$, mean \pm standard error) in five markets monitored in 2010 in Bamako, Mali

\begin{tabular}{|c|c|c|c|c|c|c|c|}
\hline Month & $\begin{array}{c}\text { Cowpea } \\
\text { hay }\end{array}$ & $\begin{array}{l}\text { Groundnut } \\
\text { haulm }\end{array}$ & $\begin{array}{c}\text { Cottonseed } \\
\text { cake }\end{array}$ & $\begin{array}{l}\text { Bush } \\
\text { hay }\end{array}$ & $\begin{array}{l}\text { Concentrates } \\
\text { for ruminant }\end{array}$ & $\begin{array}{c}\text { Cereal } \\
\text { bran }\end{array}$ & Browse $^{2}$ \\
\hline January & $493 \pm 49^{b c}$ & $454 \pm 9^{e f}$ & $159 \pm 5^{\mathrm{a}}$ & $139 \pm 4^{b}$ & $152 \pm 3^{\mathrm{a}}$ & $144 \pm 3^{a}$ & - \\
\hline February & $568 \pm 34^{a b}$ & $494 \pm 17$ de & $174 \pm 7^{a}$ & $164 \pm 6^{a b}$ & $144 \pm 3^{\mathrm{a}}$ & $148 \pm 4^{a}$ & $298 \pm 12^{a}$ \\
\hline March & $610 \pm 20^{\mathrm{a}}$ & $533 \pm 9^{c d}$ & $162 \pm 2^{\mathrm{a}}$ & $160 \pm 28^{a b}$ & $163 \pm 3^{\mathrm{a}}$ & $145 \pm 5^{\mathrm{a}}$ & $233 \pm 36^{a}$ \\
\hline April & $561 \pm 15^{a b}$ & $503 \pm 8^{\text {de }}$ & $167 \pm 3^{a}$ & $171 \pm 7^{a b}$ & $152 \pm 4^{\mathrm{a}}$ & $146 \pm 4^{a}$ & $270 \pm 20^{a}$ \\
\hline May & $598 \pm 10^{\mathrm{a}}$ & $558 \pm 8^{b c d}$ & $165 \pm 2^{\mathrm{a}}$ & $187 \pm 7^{a b}$ & $164 \pm 3^{\mathrm{a}}$ & $139 \pm 2^{a}$ & $146 \pm 8^{b}$ \\
\hline June & $651 \pm 8^{a}$ & $597 \pm 4^{\mathrm{ab}}$ & $164 \pm 2^{\mathrm{a}}$ & $186 \pm 7^{a b}$ & $160 \pm 4^{a}$ & $138 \pm 8^{a}$ & $132 \pm 3^{b}$ \\
\hline July & $650 \pm 12^{\mathrm{a}}$ & $612 \pm 6^{a b}$ & $180 \pm 12^{\mathrm{a}}$ & $206 \pm 10^{a}$ & $157 \pm 2^{\mathrm{a}}$ & $141 \pm 2^{\mathrm{a}}$ & $164 \pm 26^{a b}$ \\
\hline August & $667 \pm 9^{a}$ & $611 \pm 6^{a b}$ & $165 \pm 3^{\mathrm{a}}$ & - & $162 \pm 5^{a}$ & $142 \pm 4^{a}$ & $189 \pm 27^{a b}$ \\
\hline September & $665 \pm 6^{a}$ & $649 \pm 9^{a}$ & $166 \pm 3^{a}$ & - & $164 \pm 5^{a}$ & $146 \pm 3^{a}$ & $111 \pm 3^{b}$ \\
\hline October & $367 \pm 11^{d}$ & $326 \pm 10^{g}$ & $163 \pm 2^{a}$ & - & $172 \pm 6^{a}$ & $131 \pm 3^{a}$ & $100 \pm 11^{b}$ \\
\hline November & $411 \pm 8^{c d}$ & $345 \pm 8^{g}$ & $163 \pm 3^{a}$ & $106 \pm 5^{b}$ & $161 \pm 4^{\mathrm{a}}$ & $132 \pm 3^{a}$ & $95 \pm 9^{b}$ \\
\hline December & $438 \pm 4^{\mathrm{cd}}$ & $387 \pm 5^{f g}$ & $164 \pm 5^{a}$ & $132 \pm 8^{b}$ & $173 \pm 6^{a}$ & $131 \pm 3^{\mathrm{a}}$ & $108 \pm 2^{b}$ \\
\hline
\end{tabular}

${ }^{1} 1 \mathrm{USD} \approx 500 \mathrm{FCFA}$

${ }^{2}$ Browse found in the markets were leaves of Combretum micranthum, Piliostigma reticulatum, Pterocarpus erinaceous, and fruit of Acacia albida.

Values with different superscript letters within the same column denote significant differences $(\mathrm{p}<0.05)$ between means for each feed type. 


\section{Table V}

Analysis of variance of the effect of season on the response variables (nutritional quality and price) of different feed types ${ }^{1}$

\begin{tabular}{|c|c|c|c|c|c|c|}
\hline Feed & $\begin{array}{l}\text { Response } \\
\text { variable }\end{array}$ & $\begin{array}{c}\text { Explanatory } \\
\text { variable }\end{array}$ & $\begin{array}{l}\text { Parameter } \\
\text { estimate }\end{array}$ & Standard error & F-value & $P>F$ \\
\hline \multirow[t]{9}{*}{ Browse } & \multirow[t]{2}{*}{ Crude protein } & Constant & 189 & 19 & 94 & 0.0006 \\
\hline & & Late dry & -61 & 24 & 6 & 0.0435 \\
\hline & \multirow[t]{3}{*}{ ME } & Constant & 9.5 & 0.2 & 2,683 & $<0.0001$ \\
\hline & & Early dry & -0.9 & 0.2 & 20 & 0.0114 \\
\hline & & Late dry & 0.7 & 0.2 & 10 & 0.0353 \\
\hline & \multirow[t]{2}{*}{ IVOMD } & Constant & 668 & 11 & 3,754 & $<0.0001$ \\
\hline & & Early dry & -83 & 14 & 33 & 0.0353 \\
\hline & \multirow[t]{2}{*}{ Price } & Constant & 91 & 18 & 25 & 0.0039 \\
\hline & & Late dry & 166 & 34 & 24 & 0.0045 \\
\hline \multirow[t]{5}{*}{ Cereal bran } & \multirow[t]{2}{*}{ IVOMD } & Constant & 647 & 24 & 717 & $<0.0001$ \\
\hline & & Early dry & -61 & 31 & 4 & 0.0436 \\
\hline & \multirow[t]{3}{*}{ ME } & Constant & 9.3 & 0.3 & 745 & $<0.0001$ \\
\hline & & Early dry & -0.9 & 0.4 & 4 & 0.0425 \\
\hline & & Late dry & -0.8 & 0.4 & 4 & 0.050 \\
\hline \multirow[t]{2}{*}{ Cottonseed cake } & \multirow[t]{2}{*}{ Price } & Constant & 165 & 5 & 1,119 & $<0.0001$ \\
\hline & & Late dry & 23 & 8 & 7 & 0.0098 \\
\hline \multirow[t]{3}{*}{ Groundnut haulm } & \multirow[t]{3}{*}{ Price } & Constant & 613 & 15 & 1,609 & $<0.0001$ \\
\hline & & Early dry & -215 & 20 & 120 & $<0.0001$ \\
\hline & & Late dry & -87 & 20 & 20 & $<0.0001$ \\
\hline \multirow[t]{6}{*}{ Cowpea hay } & \multirow[t]{3}{*}{ Crude protein } & Constant & 217 & 16 & 188 & $<0.0001$ \\
\hline & & Early dry & -59 & 19 & 10 & 0.0032 \\
\hline & & Late dry & -55 & 20 & 8 & 0.0080 \\
\hline & \multirow[t]{3}{*}{ Price } & Constant & 659 & 22 & 865 & $<0.0001$ \\
\hline & & Early dry & -228 & 27 & 73 & $<0.0001$ \\
\hline & & Late dry & -72 & 28 & 7 & 0.0142 \\
\hline \multirow[t]{5}{*}{ Bush hay } & \multirow[t]{3}{*}{ Crude protein } & Constant & 36 & 5 & 52 & $<0.0001$ \\
\hline & & Early dry & -23 & 7 & 9 & 0.0081 \\
\hline & & Late dry & -16 & 6 & 7 & 0.0157 \\
\hline & \multirow[t]{2}{*}{ Price } & Constant & 175 & 8 & 474 & $<0.0001$ \\
\hline & & Early dry & -59 & 19 & 9 & 0.008 \\
\hline
\end{tabular}

1 Only variables that were significant at $\mathrm{p}<0.05$ were included.

ME: metabolizable energy; IVOMD: in vitro organic matter digestibility

areas in Burkina Faso. Because of the low prices of livestock feeds in rural areas, feed sellers in urban and suburban areas tend to buy their products from these markets. In addition, in rural areas there are local buyers or collectors of crop residues, particularly cowpea hay, groundnut haulm and bush hay, who often transport these feeds with donkeys and camels to urban and suburban areas for sale mainly to feed sellers. The System-Wide Livestock Program reports negative environmental impacts of total removal of crop residues from soil, driven partly by market opportunities in urban and suburban areas in a study based on trade-offs between stover and haulm in the dry savannah of Ghana, Nigeria and Niger (25). But this trend of total removal of crop residues from soil will probably continue in the region (14).

These results reaffirm that the major production cost in urban and suburban livestock husbandry in the Sahel is feed cost which often accounts for at least $60 \%$ of total costs (10). The high cost of feeds in suburban areas raises the question of profitability of livestock husbandry in this zone. In a study on suburban smallholder dairy production by Debrah et al. (10) in Bamako in 1990, the authors reported that the production cost ranged from 110 to 195 FCFA per liter of milk, whereas a liter of milk was sold between 100 and 250 FCFA, which showed that the profit was minimal if any at all, if milk alone was considered as the farm product. Although this study is old, the trend concerning the profitability of smallholder dairy in a suburban zone is not likely to be different today, even if the milk price has increased in Bamako compared to that of the 1990s. Optimization of livestock feeding strategies in terms of what and how much is offered is therefore critical to reduce waste, enhance resource use efficiency and thus generate profit in these urban and suburban areas $(18,22)$. It will be necessary to provide information or practical guidelines on what to feed the animals, what quantities, and in what 
Table VI

Four scenarios ${ }^{1}$ for the feed costs of sheep fattening in the West African Sahel based on diets formulated in Table I

\begin{tabular}{|c|c|c|c|c|}
\hline & & Sce & ario & \\
\hline & $\begin{array}{l}\text { Early dry season } \\
\text { sale - Tabaski }\end{array}$ & $\begin{array}{l}\text { Early dry season } \\
\text { sale - Normal }\end{array}$ & $\begin{array}{l}\text { Late dry season } \\
\text { sale - Tabaski }\end{array}$ & $\begin{array}{c}\text { Late dry season } \\
\text { sale - Normal }\end{array}$ \\
\hline a. Total feed required for 90 days' fattening (kg DM) & 135 & 135 & 135 & 135 \\
\hline $\begin{array}{l}\text { b. Total feed cost for cowpea-based diet if } 100 \mathrm{~kg} \\
=29,008 \mathrm{FCFA}^{2} \text { in early dry season and } 39,480 \text { in late } \\
\text { dry season }\end{array}$ & 39,160 & 39,160 & 53,298 & 53,298 \\
\hline $\begin{array}{l}\text { c. Total feed cost for concentrate-based diet if } 100 \mathrm{~kg} \\
=15,406 \text { FCFA in early dry season and } 15,870 \text { in late } \\
\text { dry season }\end{array}$ & 20,798 & 20,798 & 21,425 & 21,425 \\
\hline $\begin{array}{l}\text { d. Buying price of } 25 \mathrm{~kg} \text { ram at } 400 \mathrm{FCFA} / \mathrm{kg} \text { in early } \\
\text { dry season and } 300 \text { in late dry season }\end{array}$ & 10,000 & 10,000 & 7,500 & 7,500 \\
\hline e. Sales price at $34 \mathrm{~kg}$ (FCFA) & 57,800 & 28,900 & 51,000 & 25,500 \\
\hline f. Net return for cowpea-based diet $(e, b, d)$ (FCFA) & 8,640 & $-20,260$ & $-9,798$ & $-35,298$ \\
\hline g. Net return for concentrate-based diet (e, c, d) (FCFA) & 27,002 & $-1,898$ & 22,075 & $-3,425$ \\
\hline
\end{tabular}

${ }^{1}$ Duration of fattening was 90 days; daily diet offered (on dry matter basis) was $1.5 \mathrm{~kg}$. In the early dry season the price of ram during an ordinary period was assumed to be 850 FCFA/kg live weight (LW), whereas it was twice that during the Tabaski (1,700 FCFA/kg LW). If the initial weight was $25 \mathrm{~kg}$ and average daily gain was $100 \mathrm{~g} / \mathrm{day}$ (Ayantunde et al., 2008), the selling weight was $34 \mathrm{~kg}$. For the late dry season the price of ram during an ordinary period was assumed to be $750 \mathrm{FCFA} / \mathrm{kg}$ LW, whereas it was twice that during the Tabaski $(1,500 \mathrm{FCFA} / \mathrm{kg} \mathrm{LW})$. The sales price of animals was generally cheaper in the late dry season because many animals were for sale in the markets due to feed scarcity.

$21 \mathrm{USD} \approx 500 \mathrm{FCFA}$

combinations with other feeds to meet different production objectives. However, it has to be emphasized that there are livestock keepers in urban and suburban areas of West Africa's Sahel whose objective is not strictly to make profit, particularly those who are relatively wealthy. These livestock keepers establish livestock enterprises, often smallholder dairy with crossbred cows (local breeds crossed with European breeds) as an expression of their wealth and sometimes of their culture, especially those who are from pastoral ethnic groups. For poor livestock keepers in urban and suburban areas, the challenge of making profit through their livestock enterprise is always present and they address this by taking their animals to graze on the outskirts of towns thereby reducing feed cost.

The high prices of feed types such as cowpea hay and groundnut haulm in the markets we monitored were a reflection of the high demand for these feeds and not of their quality as shown by the results of the relationship between price and quality. For example, the prices of cowpea hay and groundnut haulm were at least twice that of concentrate feeds for most of the year despite the fact that their nutritional quality in terms of crude protein, ME and IVOMD was comparable all year round. Livestock keepers could easily reduce their feed cost by feeding concentrates instead of cowpea hay and groundnut haulm but this did not happen for two reasons. Firstly, there is a general perception among livestock keepers in suburban areas of West Africa's Sahel that cowpea hay and groundnut haulm are the best feeds particularly for animal fattening and for dairy cows (5). Its origin might be found in the long tradition of feeding animals with cowpea hay and groundnut haulm (3). Secondly, concentrates for ruminants are relatively new in the markets in Bamako and livestock keepers are not yet well informed on the nutritional quality of these feeds, which might have accounted for their low demand and low price despite their good nutritional quality. However, it has to be noted that concentrates cannot completely replace cowpea hay and groundnut haulm because ruminants need fiber in their diet.

Given the growing livestock population in urban and suburban areas of West Africa's Sahel and the associated rise in the demand for livestock feeds $(5,11,15)$, there are market opportunities for fodder production in the region. Fodders can be grown along the banks of Niger River in Bamako, Mali, and Niamey, Niger, but they will have to face stiff competition for land from vegetable and crop production which is widespread along the river banks (15) in both cities. In addition, available land is decreasing in most suburban areas of West Africa as a result of increased urbanization (1). Another challenge to fodder production is availability of seed because most of the varieties of cowpea and groundnut in the region are mainly for grain production and they are unsuitable for fodder production (18). According to these authors forage yield and quality are not often part of selection criteria in groundnut improvement programs in West Africa. In the case of cowpea, dual-purpose varieties have been developed in the region but the adoption has been local and low (24).

The results of the nutritional quality of different feed types sold at the five feed markets in Bamako generally agree with results in the West African Sahel reported by other authors $(3,5,17,20,23)$. For example, the values in our study of 284 to $390 \mathrm{~g} / \mathrm{kg}$ DM for crude protein content for cottonseed cake were similar to those reported by Kiema et al. (17), and Sanon et al. (23). The values in our study for crude protein content of groundnut haulm were slightly higher than those of 82 to $126 \mathrm{~g} / \mathrm{kg}$ DM reported by Nantoumé et al. (20). This could be attributed to a higher leaf to stem ratio of groundnut haulm sold in the markets compared to those used in the feeding trials by the above-mentioned authors as reflected by lower NDF 
and ADF values in our study than those reported by these authors (20). The nutritional quality of the browse species (Combretum micranthum, Piliostigma reticulatum, Pterocarpus erinaceous) sold at the surveyed markets was generally good in terms of crude protein, digestibility and ME. However, their tannin content is a major limiting factor to their nutritional value in the diet of ruminants (5).

The analysis of variance revealed that the quality of feed did not influence the price but that the season did. Moreover, the results confirmed that the interplay between demand and supply, which is largely influenced by the season with respect to crop residues, determines the prices in suburban markets (14). The high cost of crop residues (cowpea hay, groundnut haulm and bush hay) in the wet season could be attributed to the acute scarcity of these feeds during this period as markets still depended on crop residues from the previous cropping season and, by then, the stocks were usually very low. In addition, the high costs of cowpea hay and groundnut haulm observed in this study could also be attributed to the high demand in the wet season because of the Tabaski. In view of the availability of pastures in the wet season on the outskirts of many towns in the West African Sahel, Graef et al. report that many livestock keepers usually take out their animals for grazing during the day and give them supplements such as cottonseed cake, cereal bran, cowpea hay and groundnut haulm upon return (15). According to these authors, livestock keepers in urban and suburban areas that cannot take out their animals for grazing because of the nature of their work usually hire herders often paid in cash to do it. From the perspective of price, livestock feeds (crop residues) prices are lowest in the early dry season, particularly after the grain harvest. Livestock keepers could take advantage of this situation by buying crop residues at that time although their bulkiness poses the problem of storage.

The cost-benefit analysis of using cowpea hay and concentrate feed for sheep fattening showed that it was not profitable in suburban areas during an ordinary period. However, it was profitable during the Tabaski when the sales price of sheep was generally high. Sheep fattening in the West African Sahel is mainly driven by the Tabaski because of the large Muslim population in the region (4). Despite the high price of cowpea hay and groundnut haulm, many people in suburban areas still used them for sheep fattening but often offered these feeds in much lower quantities than we assumed in our analysis to minimize costs. Besides, many people did not usually offer a balanced diet to their animals at the quantity assumed in our calculations and for the whole duration of fattening.

\section{CONCLUSION}

As a result of the increase in livestock population and the associated growth in the demand for feeds, feed markets have sprung up in many cities and towns of West Africa's Sahel. Results from the survey of five livestock feed markets in Bamako showed that there was no relationship between feed price and quality but that the main determinant was the season. In view of the high price of crop residues, particularly cowpea hay and groundnut haulm, there are market opportunities for fodder production in suburban areas of West Africa's Sahel. More studies are needed to understand further the reasons for the high prices of some feeds such as cowpea hay and groundnut haulm over most of the year, and to investigate the social economic profiles of feed buyers, their reasons for buying different feed types, and their perception of feed quality. Future studies should also assess the cost and benefit of selling feeds, seasonal variations in volumes of different feeds, provenance of feeds, and sellers' perception of quality.

\section{REFERENCES}

1. AFRICAN DEVELOPMENT BANK, 2014. The Bank's human capital strategy for Africa (2014-2018). Tunis, Tunisa, African Development Bank, OSHD.

2. AGRICULTURAL AND FOOD RESEARCH COUNCIL, 1993. Energy and protein requirements of ruminants. Wallingford, UK, CAB International.

3. AYANTUNDE A.A., DELFOSSE P., FERNANDEZ-RIVERA S., GERARD B., DAN-GOMMA A., 2007. Supplementation with groundnut haulms for sheep fattening in the West African Sahel. Trop. Anim. Health Prod., 39: 207-216.

4. AYANTUNDE A.A., FERNANDEZ-RIVERA S., DAN-GOMMA A., 2008. Sheep fattening with groundnut haulms and millet bran in the West African Sahel. Rev. Elev. Méd. Vét. Pays Trop., 61: 215-220.

5. BAYALA J., KY-DEMBELE C., KALINGANIRE A., OLIVIER A., NANTOUME H., 2014. A review of pasture and fodder production and productivity for small ruminants in the Sahel. Nairobi, Kenya, World Agroforestry Centre. (ICRAF Occasional Paper No 21)

6. DE BOEVER J.L., COTTYN B.G., VANACKER J.M., BOUCQUE C.V., 1995. The use of NIRS to predict the chemical composition and the energy value of compound feeds for cattle. Anim. Feed Sci. Technol., 51: 243-253.

7. BULDGEN A., DETIMMERMAN F., PIRAUX M., COMPERE R., 1992. Sheep fattening techniques in the sahelo-sudanese region of Senegal. Rev. Elev. Méd. Vét. Pays trop., 45: 321-328. [in French with English abstract]

8. CELLULE DE PLANIFICATION ET DE STATISTIQUE, 2001. Recueil des statistiques du secteur rural. Bamako, Mali, ministère du Développement rural.

9. DAN-GOMMA A., 1998. Influence du type de fourrage et de différents niveaux de supplément en son de mil sur les performances de croissance et à I'abattage des ovins au Niger. Mém. Diplôme Ing. Agron., Institut agronomique et vétérinaire Hassan II, Rabat, Maroc, 71 p.

10. DEBRAH S., SISSOKO K., SOUMARE S., 1995. Economic study of dairy production in the area around Bamako (Mali). Rev. Elev. Méd. Vét. Pays Trop., 48: 101-109. [in French with English abstract]

11. DIOGO R.V.C., BUERKERT A., SCHLECHT E., 2010. Resource use efficiency in urban and peri-urban sheep, goat and cattle enterprises. Animal, 4: 1725-1738.

12. DIOGO R.V.C., SCHLECHT E., BUERKERT A., RUFFINO M.C., VAN WIJK M.T., 2013. Increasing nutrient use efficiency through improved feeding and manure management in urban and peri-urban livestock units of a West African city: A scenario analysis. Agric. Syst., 114: 64-72.

13. DIRECTION NATIONALE DES PRODUCTIONS ET DES INDUSTRIES ANIMALES, 2013. Rapport annuel sur les effectifs de cheptel au Mali en 2012. Bamako, Mali, ministère de l'Elevage et de la Pêche.

14. FAO, 2014. Crop residues and agro-industrial by-products in West Africa: Situation and way forward for livestock production. Rome, Italy, FAO

15. GRAEF S., SCHLECHT E., BUERKERT A., 2008. Opportunities and challenges of urban and peri-urban agriculture in Niamey, Niger. Outl. Agric., 37: 47-56.

16. HIERNAUX P., AYANTUNDE A.A., 2004. The Fakara: a semi-arid agro-ecosystem under stress. Niamey, Niger, ICRISAT / Desert Margins Programme, $95 \mathrm{p}$.

17. KIEMA A., NIANOGO A.J., OUEDRAOGO T., SOMDA J., 2008. Valorisation des ressources alimentaires locales dans l'embouche ovine paysanne : performances technicoéconomiques et options de diffusion. Cah. Agric., $17: 23-27$.

18. LARBI A., DUNG D.D., OLORUNJU P.E., SMITH J.W., TANKO R.J., MUHAMMAD I.R., ADEKUNLE I.O., 1999. Groundnut (Arachis hypogaea) for food and fodder in crop-livestock systems: forage and seed yields, chemical composition and rumen degradation of leaf and stem fractions of 38 cultivars. Anim. Feed Sci. Technol., 77: 33-47.

19. MILLOGO V., OUEDRAOGO G.A., AGENAS S., SVENNERSTENSJAUNJA K., 2008. Survey on dairy cattle milk production and milk quality problems in peri-urban areas in Burkina Faso. Afri. J. Agric. Res., 3: 215-224.

20. NANTOUME H., KOURIBA A., TOGOLA D., OUOLOGUEM B., 2000. Evaluation of the feeding value of forages and byproducts used for feeding small ruminants. Rev. Elev. Méd. Vét. Pays Trop., 53: 279-284. [in French with English abstract] 
21. RISCHKOWSKY B., SIEGMUND-SCHULTZE M., BEDNARZ K., KILLANGA S., 2006. Urban sheep keeping in West Africa: Can socioeconomic household profiles explain management and productivity? Hum. Ecol., 34: 785-807.

22. SANON H.O., KANWE B.A., 2002. Les cultures fourragères pour des productions animales durables. In : Forum national de la recherche scientifique et des innovations technologiques, Ouagadougou, Burkina Faso, 11-18 mai 2002

23. SANON H.O., KABORE-ZOUNGRANA C., LEDIN I., 2008. Nutritive value and voluntary feed intake by goats of three browse fodder species in the Sahelian zone of West Africa. Anim. Feed Sci. Technol., 144: 97-110.

24. SINGH B.B., LARBI, A., TABO R., DIXON A.G.O., 2004. Trends in development of crop varieties for improved crop-livestock systems in West Africa. In: Williams T.O., Tarawali S.A., Hiernaux P., FernandezRivera S. Eds., Sustainable crop-livestock production for improved livelihoods and natural resource management in West Africa. Nairobi, Kenya, ILRI / Wageningen, Netherlands, CTA, p. 371-388.
25. SYSTEM-WIDE LIVESTOCK PROGRAMME, 2010. Balancing livestock needs and soil conservation: Assessment of opportunities in intensifying cereal-legume-livestock systems in West Africa. Final Report. Addis Ababa, Ethiopia, ILRI

26. STATISTICAL ANALYSIS SYSTEM INSTITUTE, 1987. SAS/STAT for personal computers. Cary, NC, USA, SAS Institute.

27. TIFFEN M., 2004. Population pressure, migration and urbanization: impacts on crop-livestock systems development in West Africa. In: Williams T.O., Tarawali S.A., Hiernaux P., Fernandez-Rivera S. Eds., Sustainable crop-livestock production for improved livelihoods and natural resource management in West Africa. Nairobi, Kenya, ILRI / Wageningen, Netherlands, CTA, p. 3-27.

Accepté le 01.10.2014

\section{Résumé}

Ayantunde A.A., Blummel M., Grings E., Duncan A.J. Prix et qualité des aliments du bétail dans les marchés périurbains du Sahel Ouest africain : étude de cas à Bamako, Mali

Dans les villes du Sahel Ouest africain, les activités liées à l'élevage, comme la production laitière des petits exploitants et l'engraissement du bétail (bovins, ovins et caprins), sont devenues très répandues pour satisfaire aux besoins en alimentation du ménage et pour générer des revenus. L'importance accrue de l'agriculture urbaine et périurbaine, en particulier des activités d'élevage dans la région, a contribué à une croissance rapide du cheptel dans la plupart des grandes villes. En réponse à cette croissance et, ainsi, à la demande accrue en aliments, des marchés des aliments du bétail se sont développés dans plusieurs grandes villes du Sahel Ouest africain. Une enquête sur les marchés des aliments du bétail a été conduite au Mali dans cinq marchés de Bamako. Le prix des aliments a été suivi mensuellement de janvier à décembre 2010. En outre, des échantillons d'aliments ont été collectés pour analyser leur qualité nutritionnelle. Les résultats ont montré que les prix de la fane de niébé et de la fane d'arachide étaient plus élevés que ceux des autres aliments tout au long de l'année. Le prix de la fane de niébé a varié entre $367 \mathrm{FCFA} / \mathrm{kg}$ de matière sèche $(1 \mathrm{USD} \approx 500 \mathrm{FCFA})$ en octobre, soit juste après la récolte, et 667 FCFA $/ \mathrm{kg}$ en août, pendant la saison humide. Les résultats ont également montré qu'il n'y avait pas de relation entre le prix et la qualité pour tous les types d'aliments. Cependant, leur prix et leur qualité ont considérablement varié en fonction des saisons, indiquant que la saison était un déterminant majeur du prix des aliments de bétail dans les zones périurbaines du Sahel Ouest africain.

Mots-clés: Bétail - Agriculture périurbaine - alimentation pour animaux - Prix - Qualité - Valeur nutritive - Marché des produits agricoles - Sahel.

\section{Resumen}

Ayantunde A.A., Blummel M., Grings E., Duncan A.J. Precio y calidad de alimento para ganado en mercados suburbanos en el Sahel de África del Oeste: Análisis de un caso en Bamako, Malí

En las ciudades del Sahel de África del Oeste, la cría de ganado, en forma de pequeños productores lecheros y de engorde de carne (bovino, ovino y caprino), se está tornando popular entre los propietarios de ganado, con el fin de satisfacer las necesidades en alimento para los hogares y para generación de ingresos. La creciente importancia de agricultura urbana y suburbana en la región, particularmente cría de ganado, ha llevado a un aumento rápido de la población de ganado en la mayoría de las ciudades y pueblos grandes. Como resultado de este aumento en la población de ganado y el crecimiento asociado con la demanda de alimentos, han surgido mercados alimenticios en varias ciudades y pueblos del Sahel de África del Oeste. Una encuesta sobre los mercados de alimentación de ganado fue llevada a cabo en cinco mercados de Bamako, Malí. Los precios de los alimentos de ganado fueron monitorizados mensualmente de enero a diciembre 2010. Además, se colectaron muestras de alimentos de los mercados para análisis de laboratorio, con el fin de determinar la calidad nutricional. Los resultados muestran que los precios de heno de caupí y tallo de maní fueron consistentemente más elevados que los de otros alimentos a lo largo del año. El precio del heno de caupí varió alrededor de $367 \mathrm{FCFA} / \mathrm{kg}$ de materia seca (MS) (1 USD $\approx 500$ FCFA) en octubre, por ejemplo inmediatamente después de la cosecha, hasta 667 FCFA/kg MS en agosto, por ejemplo durante la estación seca. Los resultados también muestran que no hubo relación entre precio y calidad para todos los alimentos. Sin embargo, los precios y la calidad de los alimentos difirieron significativamente a través de las estaciones, sugiriendo que la estación fue un mayor determinante para el precio de los alimentos de ganado en las zonas suburbanas del Sahel del Oeste de África.

Palabras clave: Ganado - Agricultura peri urbana - Pienso Precio - Calidad - Valor nutritivo - Mercado de productos básicos - Sahel. 
